\title{
THE DISTRIBUTION OF COASTAL GROUP LANDHOPPERS (CRUSTACEA: AMPHIPODA: TALITRIDAE) RELATED TO SEA SPRAY AT COX BIGHT, TASMANIA
}

\author{
by Alastair M.M. Richardson
}

(with four tables and four text-fig ures)

Richardson, A.M.M., 1993 (31:viii): The distribution of coastal group landhoppers (Crustacea: Amphipoda: Talitridae) related to sea spray at Cox Bight. Pap. Proc. R. Soc. Tasm. 127: 55-60. https://doi.org/10.26749/rstpp.127.55 ISSN 0080-4703. Department of Zoology, University of Tasmania, GPO Box 252C, Hobart, Tasmania 7001.

Terrestrial amphipod crustaceans from two ecological groups, the coastal group and the forest group, were collected along two transects at right angles to the shoreline at Cox Bight, south western Tasmania. The transects were placed on either side of Point Eric to ensure that one was more sheltered from seaspray, in order to examine the hypothesis that the distribution of coastal group landhoppers is controlled by the inland penetration of ionic precipitation.

Coastal species extended twice as far inland on the exposed transect, and their distribution on both transects correlated strongly with raised levels of sodium in the soil, providing good circumstantial support for the hypothesis. The study highlights the ecological importance of the coastal zone in the World Heritage Area. Further studies should examine the effect of manipulating soil ion levels on the distribution of coastal species.

Key Words: Western Tasmania, landhoppers, Talitridae, ionic precipitation.

\section{INTRODUCTION}

The Tasmanian terrestrial amphipod fauna can be divided into three ecological groupings: the eastern forest group, the western forest group and the coastal group (Friend 1987a), depending on their distribution. The coastal group comprises species which, although fully terrestrial in other respects, are restricted to a narrow zone immediately above the high tide mark. Friend (1987a) records four species in this group, but recent collections have revealed undescribed species from the coastal zone in the genera Keratroides, Austrotroides and Tasmanorchestia, raising the number of species in the group to at least seven (Friend 1987b, Richardson \& Swain 1988, 1990, Richardson et al. 1991).

Richardson et al. (1991) described the fine-scale distribution of landhoppers above the high tide mark on transects at South Cape Bay, Mulcahy Bay and Hibbs Bay, on the south and west coasts. They recorded ten species of landhoppers, including four coastal group species. They found that species in the coastal group extended between 30 and $50 \mathrm{~m}$ inland at South Cape Bay, but over $70 \mathrm{~m}$ (the full extent of the transect) inland at Hibbs Bay. Although they were unable to demonstrate any relationship between the distribution of coastal group species and the $\mathrm{Na}$ content of the substrate at South Cape Bay (the only site where soil samples were collected), the greater inland penetration of the coastal group species at Hibbs Bay, which is more exposed to westerly winds than South Cape Bay, suggests that ion precipitation may control their distribution.

This study aims to demonstrate, indirectly, a relationship between ionic precipitation and the distribution of coastal group landhoppers at Cox Bight, a few kilometres southeast of Melaleuca. It was not possible to make measurements of ion precipitation, and the actual rates of precipitation will be strongly related to weather conditions; but, as an alternative, soil concentrations of $\mathrm{Na}$ were used as a measure of ion precipitation. It was assumed that sea spray will penetrate further inland where the shore is more exposed to westerly winds. Thus, the westward and eastward-facing sides of Point Eric, a relatively high rocky point which separates the two halves of Cox Bight, might be expected to receive different amounts of ion precipitation, according to their exposure. The hypothesis being examined here (Friend 1987a, b, Richardson et al. 1991) is that coastal group amphipods will penetrate further inland where ionic precipitation, as estimated by soil $\mathrm{Na}$ levels, penetrates further inland.

\section{METHODS}

Cox Bight is a deeply indented bay in the south coast of Tasmania, about $8 \mathrm{~km}$ southeast of the Melaleuca airstrip. Thebay is divided into two by Point Eric, a rocky promontory which reaches a height of $40-80 \mathrm{~m}$ a.s.l. The bay faces almost due south.

At the top of the beach there is a low dune ridge of varying height, and immediately behind it a band of low ( $<6 \mathrm{~m}$ ) coastal woodland, similar to the NIT0 community of Kirkpatrick et al. (1988), dominated by dogwood, Pomaderris apetala, and Eucalyptus nitida, with an understorey of cutting grass, Gahnia grandis, laurel, Anopterus glandulosus, bracken, Pteridium esculentum and other ferns. This woodland band is 40-60 m deep and then gives way, via a fairly sharp ecotone of Melaleuca squarrosa, to a wet heathland variously dominated by buttongrass, Gymnoschoenus sphaerocephalus, $M$. squamea and other heathy shrubs, close to the B1 a community of Jarman et al. (1988). The overall height of this heathland community declines further inland, as the ground rises. There are occasional small copses of low E. nitida, the B12 community of Jarman et al. (1988).

Two transects were laid out on either side of Point Eric, one to the east ("east transect"), the other to the west ("west transect"), with their starting points at approximately DM388843 and DM385842, respectively (Tasmap 1:100 000 Sheet 8111 , Old River). The transects ran from immediately above the high tide mark directly inland, at right angles to the tideline. The east transect was $150 \mathrm{~m}$ long, but the west transect was restricted to $106 \mathrm{~m}$ by an outcrop of large rocks. 
At $2 \mathrm{~m}$ intervals along each transect, pitfall traps were set. Each trap consisted of a plastic drinking cup of $50 \mathrm{~mm}$ diameter and $100 \mathrm{~mm}$ depth, let into the soil so that their lips were flush with the soil surface. A plastic Petri dish lid was supported on three twigs over each trap to exclude rainwater, and 5-10 $\mathrm{ml}$ of saturated picric acid was placed in each as a non-volatile preservative. Identical traps were used in the earlier study by Richardson et al. (1991).

The traps were left in place for 13-14 days, and the catch was then emptied from each trap into a labelled vial containing $70 \%$ ethanol. At each trap site, a sample was taken from the surface soil, after the leaf litter layer had been removed. The soil samples were stored in Clipseal ${ }^{\mathrm{TM}}$ bags and transported within 3-4 days to the laboratory, where they were stored in a deep freeze.

The landhoppers were identified, using Friend's (1987a) key and collections made in the area previously (Richardson \& Swain 1990); the numbers of adult males, females and juveniles were counted. The moisture content of the soil samples was calculated after drying for $48 \mathrm{~h}$ at $110^{\circ} \mathrm{C}$. Subsamples of the dried soil were ashed at $450^{\circ} \mathrm{C}$ for $4 \mathrm{~h}$ and reweighed to calculate weight loss on ignition. A fixed weight $(1 \mathrm{~g})$ of dry soil was mixed with $100 \mathrm{ml}$ of distilled
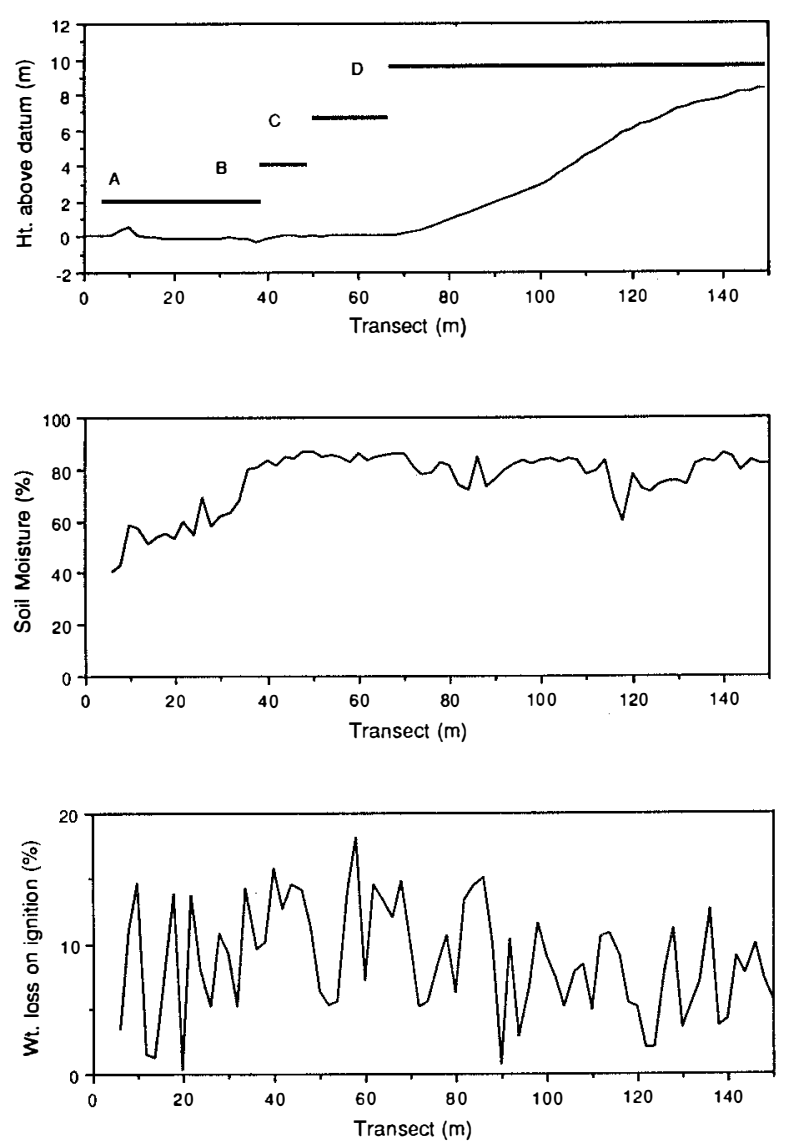

FIG. 1 - Profile of the sheltered transect, to the east of Point Eric, showing the vegetation communities, and the levels of soil moisture and organic content (as weight loss on ignition) along the transect. $A=3 \mathrm{~m}$ high coastal woodland with Eucalyptus nitida, Melaleuca squarrosa, Gahnia grandis and bracken; $B=1.5 \mathrm{~m}$ tall $\mathrm{M}$. squarrosa; $C=1 \mathrm{~m}$ tall $\mathrm{M}$. squarrosa; $D=0.75 \mathrm{~m}$ tall heathy sedgeland with buttongrass and woody shrubs, and a small copse of $\mathrm{E}$. nitida. water and allowed to stand for $24 \mathrm{~h}$. The $\mathrm{Na}$ content of the supernatant was measured by flame photometry.

\section{RESULTS}

Approximate profiles of the transects and the distribution of plant communities along them are shown in figures $1 \& 2$. The west transect rises more quickly and to a slightly greater height than the east transect, but the vegetation pattern on both transects is effectively the same, although the belt of coastal woodland extends further inland on the western transect. Of the soil parameters, soil moisture and weight loss on ignition show little evidence of systematic variation along the transects. Soil moisture tends to be lower on the first $30 \mathrm{~m}$ of the east transect and the first $20 \mathrm{~m}$ of the west transect, probably reflecting the sandier nature of the soils there.

Figures $3 \& 4$ show the distribution of amphipods in relation to the transect profiles and the $\mathrm{Na}$ content of the soil. The amphipods have been grouped into the coastal group and forest group species (table 1). Because the abundances of coastal group animals at the seaward ends of
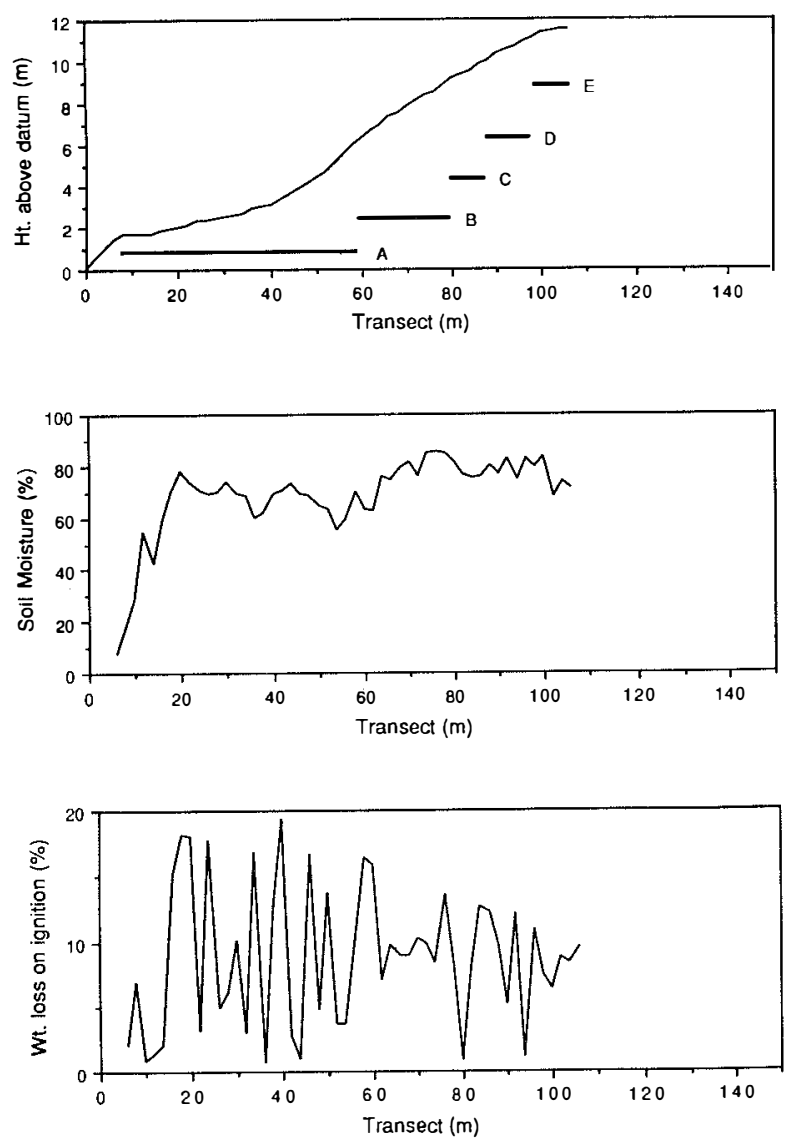

FIG. 2 - Profile of the exposed transect, to the west of Point Eric, showing the vegetation communities, and the levels of soil moisture and organic content (as weight loss on ignition) along the transect. $A=6 \mathrm{~m}$ high coastal woodland with Eucalyptus nitida, Pomaderris apetala, Anopterus glandulosus and Gahnia grandis; $B=1 \mathrm{~m}$ tall E. nitida, Melaleuca squamea and buttongrass; $C=0.5 \mathrm{~m}$ tall $\mathrm{M}$. squamea; $D=1 \mathrm{~m}$ tall heathy sedgeland with buttongrass and woody shrubs; $E=$ rock outcrop with a small copse of $\mathrm{E}$. nitida and $\mathrm{M}$. squarrosa. 
the transects were very much greater than those inland, the catches have been expressed as logarithms. Seven species of amphipods were present, three from the coastal group and four from the forest group (table 1). Keratroides vulgaris only appeared on the west transect, where it was rare.

On the east transect the coastal group species extended $24 \mathrm{~m}$ inland, or about half the depth of the coastal woodland. Forest group species first appeared $16 \mathrm{~m}$ inland, and no animals of either group were caught between 32 and $48 \mathrm{~m}$, in the inland third of the coastal woodland and the ecotone with the heathland. Forest group species were found all along the remaining length of the transect.

On the west transect the coastal group extended to $52 \mathrm{~m}$ inland, and apart from a single specimen of Neorchestia plicibrancha at $38 \mathrm{~m}$, the forest group species only appeared from the $50 \mathrm{~m}$ mark. There was no evidence of a gap in amphipod distribution at the landward edge of the coastal woodland on the west transect.

Soil sodium levels were a little higher on the seaward half of the exposed west transect than on the east transect, but on both there was a trend for soil $\mathrm{Na}$ content to decline on the inland part. In order to test whether there were significant differences between the $\mathrm{Na}$ content of the soil in different
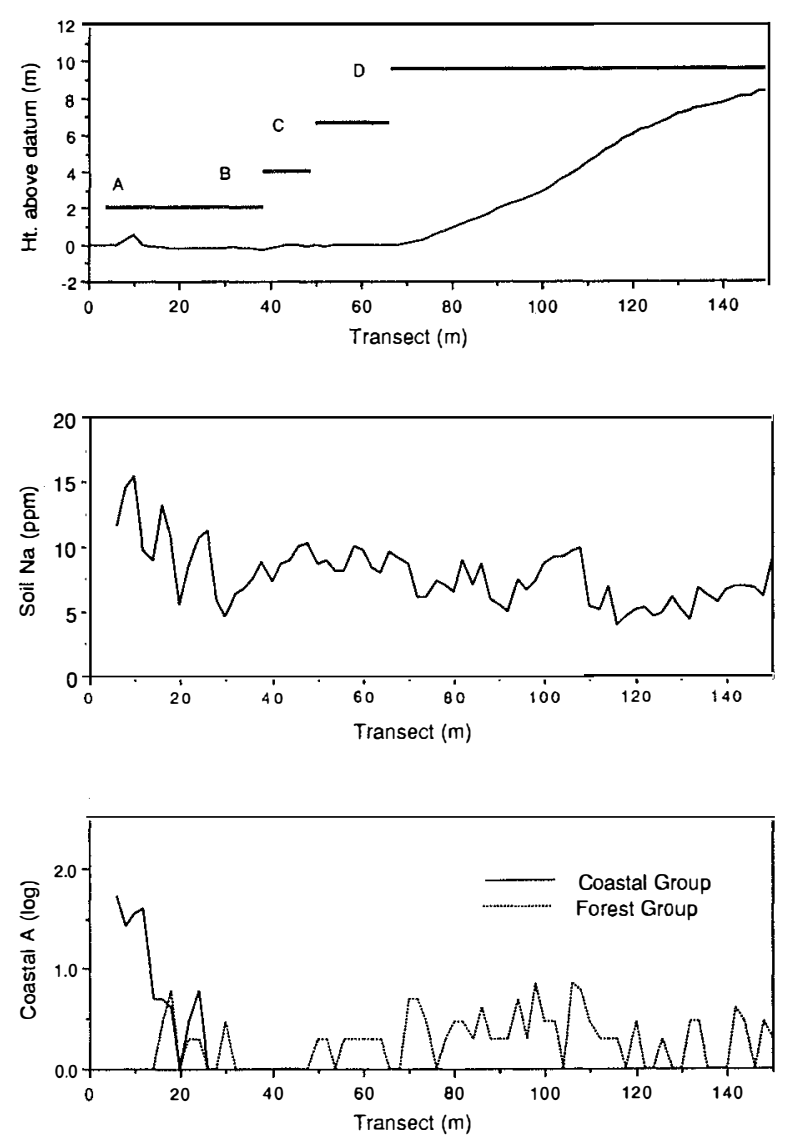

FIG. 3 - The sheltered east transect, showing the concentration of soil $\mathrm{Na}$ along the transect and the distribution of coastal and forest group amphipods. Vegetation zones as fig. 1. parts of the transects, each was divided into three sections: the section with coastal amphipod species only, with mixed coastal and forest species, and with forest species only. The $\mathrm{Na}$ content of the soil samples collected at each trap in each of these sections was compared, using a single factor analysis of variance. Soil moisture and weight loss on ignition were treated similarly (tables $2,3 \& 4$ ).

The sodium content of the soil in the section occupied by the coastal species is significantly higher than in the forest species section on both transects. Soil moisture also varies significantly between the sections, increasing from the coastal section to the forest group section.

\section{DISCUSSION}

The results of this study are consistent with the hypothesis that reduced ionic precipitation limits the landward penetration of coastal landhoppers. In a preliminary investigation of landhopper distributions at Cox Bight, Richardson \& Swain (1990) found that coastal landhoppers extended a similar distance inland on a transect to the west of Point Eric. But on a "sheltered" transect at the western end
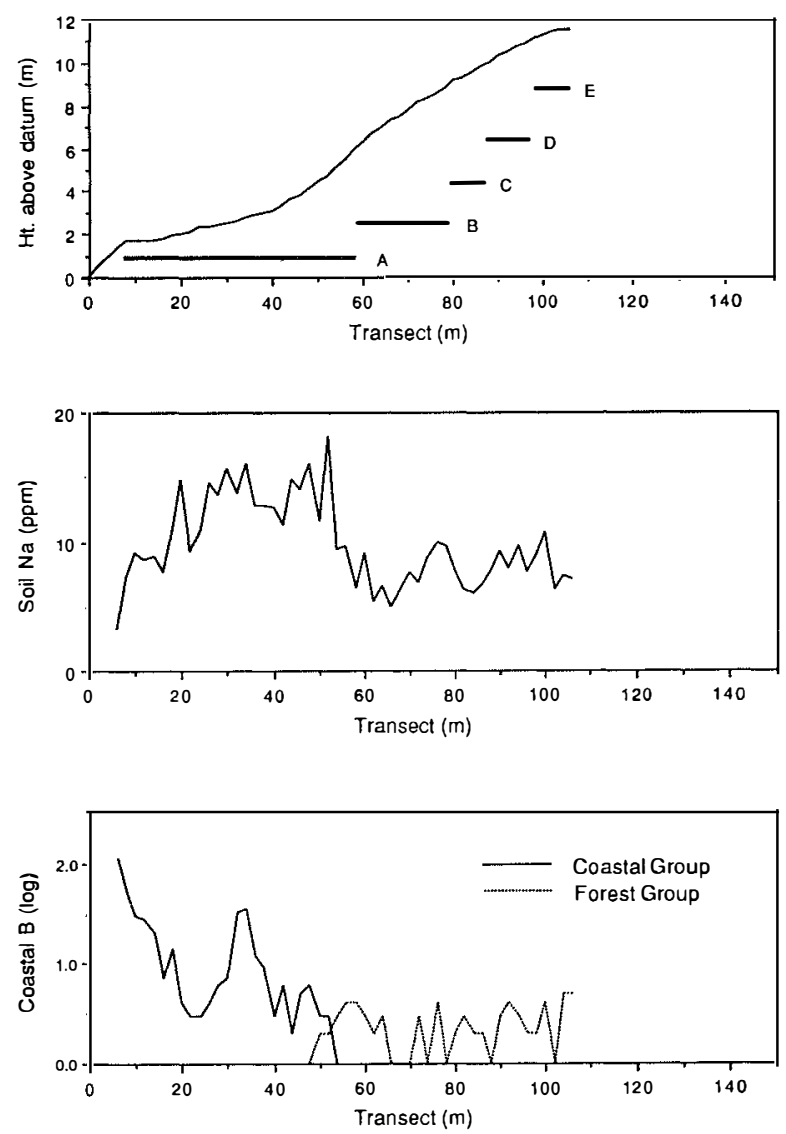

FIG. 4- The exposed west transect, showingthe concentration of soil $\mathrm{Na}$ along the transect and the distribution of coastal and forest group amphipods. Vegetation zones as fig. 2. 
TABLE 1

Landhoppers (Amphipoda: Talitridae) collected on the Cox Bight transects

\begin{tabular}{lll}
\hline & \multicolumn{1}{c}{ Coastal group } & \multicolumn{1}{c}{ Forest group } \\
\hline East transect & $\begin{array}{l}\text { Austrotroides maritimus } \\
\text { Tasmanorchestia sp. 3 } \\
\text { Keratroides rex }\end{array}$ & $\begin{array}{l}\text { Neorchestia plicibrancha } \\
\text { Austrotroides leptomerus } \\
\text { Orchestiella neambulans }\end{array}$ \\
West transect & $\begin{array}{l}\text { Austrotroides maritimus } \\
\text { Tasmanorchestia sp. 3 }\end{array}$ & $\begin{array}{l}\text { Neorchestia plicibrancha } \\
\text { Austrotroides leptomerus } \\
\text { Keratroides rex }\end{array}$ \\
& Orchestiella neambulans \\
& & \\
\hline
\end{tabular}

TABLE 2

Analysis of variance of soil $\mathrm{Na}$ content* from Point Eric

Treatments are sites with coastal amphipods only, with coastal/forest species and with forest species only:

$\mathrm{A}=$ east transect, $\mathrm{B}=$ west transect

\begin{tabular}{|c|c|c|c|c|c|c|c|c|c|c|}
\hline & \multicolumn{2}{|c|}{ Sum of squares } & \multicolumn{2}{|c|}{ DF } & \multicolumn{2}{|c|}{ Mean square } & \multicolumn{2}{|c|}{ F-ratio } & \multicolumn{2}{|c|}{ Prob. } \\
\hline & A & B & A & B & A & B & A & $\mathrm{B}$ & A & B \\
\hline Among & 0.226 & 0.381 & 2 & 2 & 0.113 & 0.191 & 11.9164 & 16.9091 & 0.00005 & $<0.00001$ \\
\hline Within & 0.665 & 0.541 & 70 & 48 & 0.009 & 0.011 & & & & \\
\hline Total & 0.891 & 0.922 & 72 & 50 & & & & & & \\
\hline
\end{tabular}

Treatment means $(\log p p m N a)$

\begin{tabular}{ccccccc}
\hline \multicolumn{2}{c}{ Coastal } & \multicolumn{2}{c}{ Coastal/forest } & \multicolumn{3}{c}{ Forest } \\
$\mathrm{A}$ & $\mathrm{B}$ & \multicolumn{2}{c}{$\mathrm{A}$} & $\mathrm{B}$ & $\mathrm{A}$ & $\mathrm{B}$ \\
\hline 1.105 & 1.058 & & 1.012 & 1.169 & 0.905 & 0.937 \\
\hline
\end{tabular}

Multiple comparisons

\begin{tabular}{|c|c|c|c|c|c|c|c|c|}
\hline \multirow[t]{2}{*}{ Comparison } & \multicolumn{2}{|c|}{ Difference } & \multicolumn{2}{|c|}{ Standard Error } & \multirow{2}{*}{$\begin{array}{c}\text { Q-value } \\
\text { A }\end{array}$} & \multicolumn{2}{|c|}{ Critical } & \multirow[b]{2}{*}{$\mathrm{B}$} \\
\hline & A & B & A & B & & $\mathrm{B}$ & A & \\
\hline Forest v coastal & 0.201 & 0.121 & 0.032 & 0.024 & $6.266 \dagger$ & $5.094 \dagger$ & 3.387 & 2.844 \\
\hline Forest vs coastal/forest & 0.107 & 0.232 & 0.032 & 0.030 & $3.351 \dagger$ & $7.661+$ & 2.821 & 3.420 \\
\hline Coastal/forest vs coastal & 0.093 & & 0.044 & & 2.142 & & 2.821 & \\
\hline Coastal vs coastal/forest & & 0.111 & & 0.033 & & $3.410 \dagger$ & & 2.844 \\
\hline
\end{tabular}

* ppm, transformed to $\log 10(\mathrm{x}+1)$.

$\dagger$ significant.

of the bay, Keratroides rex extended about $80 \mathrm{~m}$ inland, further than on either of the transects examined here. However, no soil $\mathrm{Na}$ levels were measured on the 1990 transects, and the vegetation at the far western end of the bay differs significantly from the Point Eric transects, with mature mixed forest immediately behind a narrow belt of coastal woodland. Richardson \& Swain (1990) concluded that the 1990 observations did not provide any conclusive evidence about the role of ionic precipitation.

The present observations can only provide circumstantial evidence of a relationship between ionic precipitation levels and the inland penetration of coastal group amphipods. Firstly, the relationship between soil $\mathrm{Na}$ levels, measured at an instant, and the rate of ionic precipitation is likely to be only very approximate, since the levels at any given time will depend not only on the rate of input, but also on interception by the vegetation and the rate of loss from the soil through leaching. Richardson et al. (1991) demonstrated a correlation between soil $\mathrm{Na}$ concentration and weight loss on ignition and suggested that increasing organic content would slow the leaching rate of ions. The organic content of the soil on these transects (as estimated weight loss on ignition) was lower and more variable than that measured by Richardson et al. (1991) at South Cape Bay and Hibbs Bay, but it did not appear to vary significantly between the transects. There was no strong correlation between organic 
TABLE 3

Analysis of variance of soil moisture data* from Point Eric

Treatments as table 2: $\mathrm{A}$ = east transect, $\mathrm{B}=$ west transect

\begin{tabular}{|c|c|c|c|c|c|c|c|c|c|c|}
\hline & \multicolumn{2}{|c|}{ Sum of squares } & \multicolumn{2}{|c|}{ DF } & \multicolumn{2}{|c|}{ Mean square } & \multicolumn{2}{|c|}{ F-ratio } & \multicolumn{2}{|c|}{ Prob. } \\
\hline & A & B & A & B & A & B & A & B & A & $\mathrm{B}$ \\
\hline Among & 2411.503 & 1341.402 & 2 & 2 & 1205.751 & 670.701 & 60.3242 & 9.1777 & $<0.00001$ & 0.00049 \\
\hline Within & 1399.149 & 3507.819 & 70 & 48 & 19.988 & 73.080 & & & & \\
\hline Total & 3810.652 & 4849.221 & 72 & 50 & & & & & & \\
\hline
\end{tabular}

Treatment means (\% soil moisture)

\begin{tabular}{ccccccc}
\hline \multicolumn{3}{c}{ Coastal } & \multicolumn{2}{c}{ Coastal/forest } & \multicolumn{3}{c}{ Forest } \\
A & B & A & B & A & B \\
\hline 44.904 & 48.777 & 47.958 & 55.254 & 63.066 & 60.315 \\
\hline
\end{tabular}

Multiple comparisons

\begin{tabular}{|c|c|c|c|c|c|c|c|c|}
\hline \multirow[t]{2}{*}{ Comparison } & \multicolumn{2}{|c|}{ Difference } & \multicolumn{2}{|c|}{ Standard Error } & \multicolumn{2}{|c|}{ Q-value } & \multicolumn{2}{|c|}{ Critical } \\
\hline & A & B & A & B & A & B & A & B \\
\hline Coastal v forest & 18.162 & 11.538 & 1.469 & 1.907 & $12.365 \dagger$ & $6.050 \dagger$ & 3.387 & 3.420 \\
\hline Coastal vs coastal/forest & 3.054 & 6.476 & 1.999 & 2.617 & , 1.528 & 2.474 & 2.821 & 2.844 \\
\hline Coastal/forest vs forest & 15.108 & 5.062 & 1.469 & 2.433 & $10.286 \dagger$ & 2.080 & 2.821 & 2.844 \\
\hline
\end{tabular}

* \%, transformed to arcsine.

$\dagger$ significant.

TABLE 4

Analysis of variance of weight loss on ignition data* from Point Eric

Treatments as table 2: $\mathrm{A}=$ east transect, $\mathrm{B}=$ west transect

\begin{tabular}{lrrrrrrrrrrr}
\hline & \multicolumn{3}{c}{ Sum of squares } & \multicolumn{2}{c}{ DF } & \multicolumn{2}{c}{ Mean square } & \multicolumn{2}{c}{ F-ratio } & \multicolumn{2}{c}{ Prob. } \\
& A & B & A & B & A & B & A & B & A & B \\
\hline Among & 62.921 & 52.560 & 2 & 2 & 31.461 & 26.280 & 1.3917 & 0.7040 & 0.25448 & 0.50401 \\
Within & 1582.408 & 1791.780 & 70 & 48 & 22.606 & 37.329 & & & & & \\
Total & 1645.330 & 1844.340 & 72 & 50 & & & & & & \\
\hline
\end{tabular}

* \%, transformed to arcsine.

content and $\mathrm{Na}$ content $(\mathrm{r}=0.32, \mathrm{n}=73$ for the east transect; $\mathrm{r}=0.031, \mathrm{n}=51$ for the west transect).

Secondly, there is no unequivocal way of deciding between conflicting explanations of the coastal species' distribution. Thus, their distribution could be controlled by soil moisture, which also varies systematically between the transect sections, and, of course, there may be other controlling factors which have not been identified.

It seems unlikely that the distribution of the coastal group is linked to vegetation patterns, since their landward limit does not coincide with the most obvious sharp change in the vegetation, the woodland/heathland ecotone. On both transects, the coastal species die out before the landward edge of the woodland. The diet of landhoppers is generally thought to be unspecialised (Morton \& Richardson 1984) and they show no obvious linkage to major vegetation types (Richardson 1991), so the change in litter composition is unlikely to affect them. But the absence of any major change in amphipod species at the woodland edge also suggests that the changes in microclimate which occur at that point are not important in controlling amphipod distributions.

The circumstantial evidence that ionic precipitation controls the coastal species distribution is strong. Their inland penetration on the western side of Point Eric is twice that on the sheltered eastern side, just a few hundred metres away, and their distribution on both transects correlates strongly with soil $\mathrm{Na}$ levels. The hypothesis could be examined further by a series of transects at a stretch of coastline where (a) there is a similar vegetation pattern, preferably 
forest, behind the shore; and (b) the degree of exposure (and thus ionic precipitation) changes steadily. Another, and more rigorous approach would be to manipulate the input of ions into the soil with a view to ext ending the distribution of coastal species. Similarly, transplanting populations of coastal species increasing distances inland would also provide st rong evidence.

The relationship between the forest and the coastal species on these transects is interesting, in that the forest species did not approach as close to the shore as they did at South Cape Bay or Hibbs Bay. At South Cape Bay, the forest species Mysticotalitrus tasmaniae was present almost from the seaward limit of the distribution of the coastal species while, at Hibbs Bay, Keratroides vulgaris approached to within $5 \mathrm{~m}$ of the seaward edge of the coastal species distribution. Neither of these species was common on the Point Eric transects. On the South Cape Bay and Hibbs Bay transects, the coastal vegetation was backed by forest rather than heathland, which may have provided a greater supply of forest species.

The Tasmanian landhopper fauna is apparently more diverse than any other worldwide; no other regional fauna has been shown to include species restricted to the immediate coastal zone. While the existence of halophilic land plants is well known, few examples of terrestrial groups of animals with dist ributions restricted to the coast have been recorded. A further Tasmanian example can be seen in the landsnail Bothriembryon tasmanicus, which is only found very close to the coast (Dartnall 1972, A.M.M. Richardson, pers. obs.), and other examples might be expected among the oniscoid isopods, since coastal species are known in the British fauna (Harding \& Sutton 1985, Hopkin 1991).

This study again highlights the significance of the near coastal zone in the Western Tasmania World Heritage Area (Friend 1987b, Harris et al. 1993). The combination of the ecological and phylogenetic diversiry in the talit rid fauna, and the undisturbed transitions from sea to land in the area, are a biological resource which is very rare or even unavailable elsewhere in the world.

\section{ACKNOWLEDGEMENTS}

I am very grateful to Maria Moore and Alison Phillips for carrying out the fieldwork component of this study, and to Alison Phillips for performing the soil analyses. I am also grateful to the Department of Parks, Wildlife and Heritage (now Environment and Land Management) for financial and logistic support.

\section{REFERENCES}

Dartajall, A.J., 1972: Tasmanembryon tasmanicus. Tasm. Nat. 28: 7.

FriEnd, J.A., 1987a: The terrestrial amphipods (Amphipoda: Talitridae) of Tasmania: systematics and zoogeography. Rec. Aust. Mus., Suppl. 7: 1-85.

FRIEND, J.A., 1987b: A SURVEY OF THE TERRESTRIAL AMPHIPOD FAUNA OF THE WESTERN TASMANIA WORLD HERITAGE AREA. National Parks and Wildlife Service, Hobart: $18 \mathrm{pp}$

HaRding, P.T. \& SUTTON, S.L., 1985: WOODLICE IN BRITAIN AND IRELAND: DISTRIBUTION AND HABITAT. Natural Environment Research Council, Huntingdon: $151 \mathrm{pp}$.

Harris, S., Brothers, N., Coates, F., Edgar, G.J., Last, P.R., Richardson, A.M.M. \& Wells, P., 1993: The biological significance of a coastline in the roaring forties latitudes. In Smith, S.J. \& Banks, M.R. (Eds): TASMANIAN WILDERNESS - WORLD HERITAGE VALUE. Royal Society of Tasmania, Hobart.

HopKINS, S.P., 1991: A key to the woodlice of Britain and Ireland. Field Stud. 7: 599-650.

Jarman, S.J., Kantvilas, G. \& Brown, M.J., 1988: Buttongrass moorland in Tasmania. Res. rep. Tasm. For. Res. Counc. 2, Hobart: 158 pp.

Kirkpatrick, J.B., Peacock, R.J., Cullen, P.J. \& Neytand, M.G., 1988: THE WET EUCALYPT FORESTS OF TASMANIA Tasmanian Conservation Trust, Hobart: 156 pp.

Morton, H.P. \& Richardson, A.M.M., 1984: Observations on the feeding preferences of two species of Tasmanian terrestrial amphipods (Crustacea: Amphipoda: Talitridae). Pap. Proc R. Soc. Tasm. 118: 79-84.

RICHARDSON, A.M.M., 1991: The implications of vegetation change for animals and their habitats. Tasforests 2: 173-178.

RichaRDSON, A.M.M. \& SWAIN, R., 1988: FRESHWATER AND TERRESTRLAL CRUSTACEA COLLECTIONS IN 1987 88. Department of Parks, Wildlife and Heritage, Hobart: $13 \mathrm{pp}$.

RichaRDSON, A.M.M. \& SwaIn, R., 1990:' FRESHWATER AND TERRESTRIAL CRUSTACEA. Department of Parks, Wildlife and Heritage, Hobart: 18 pp.

Richardson, A.M.M., SWain, R. \& Smirh, S.J., 1991: Local distributions of sandhoppers and landhoppers (Crustacea: Amphipoda: Talitridae) in the coastal zone of western Tasmania. Hydrobiologia 223: 127-140.

(accepted 6 May 1993) 